Supporting Information

\title{
Artificial Metalloprotease with Active Site Comprising Aldehyde Group and $\mathrm{Cu}(\mathrm{II}) \mathrm{Cyclen}$ Complex
}

Sang Ho Yoo, Byoung June Lee, Hyun Sook Kim, and Junghun Suh*

Contribution from Department of Chemistry, Seoul National University, Seoul 151-747, Korea

\section{Contents}

(1) Experimental procedures for synthesis of A5 and A5 ${ }^{\text {cont }}$

(2) Experimental procedures for synthesis of B1 and B1 ${ }^{\text {cont }}$

(3) (Figure S1) The plot of $k_{\mathrm{o}}$ against $C_{\mathrm{o}}$ for the hydrolysis of $\gamma$-globulin catalyzed by $\mathrm{Cu}(\mathrm{II}) \mathrm{A}-\mathrm{PS}(\bullet)$ and $\mathrm{Cu}(\mathrm{II}) \mathrm{A}^{\text {cont }}$-PS (०) at $\mathrm{pH} 9.5$ and $50^{\circ} \mathrm{C}$.

(4) (Figure S2) The plot of $k_{\mathrm{o}}$ against $C_{\mathrm{o}}$ for the hydrolysis of $\gamma$-globulin catalyzed by $\mathrm{Cu}(\mathrm{II}) \mathrm{B}-\mathrm{PS}(\bullet)$ and $\mathrm{Cu}(\mathrm{II}) \mathrm{B}^{\text {cont }}$-PS (०) at $\mathrm{pH} 9.5$ and $50^{\circ} \mathrm{C}$.

(5) (Figure S3) The plot of $k_{\mathrm{o}}$ against $C_{\mathrm{o}}$ for the hydrolysis of bovine serum albumin catalyzed by $\mathrm{Cu}(\mathrm{II}) \mathrm{A}-\mathrm{PS}(\bullet)$ and $\mathrm{Cu}(\mathrm{II}) \mathrm{A}^{\text {cont }}$-PS (०) at $\mathrm{pH} 9.5$ and $50^{\circ} \mathrm{C}$.

(6) (Figure S4) The plot of $k_{\mathrm{o}}$ against $C_{\mathrm{o}}$ for the hydrolysis of bovine serum albumin catalyzed by $\mathrm{Cu}(\mathrm{II}) \mathrm{B}-\mathrm{PS}(\bullet)$ and $\mathrm{Cu}(\mathrm{II}) \mathrm{B}^{\text {cont }}$-PS (०) at $\mathrm{pH} 9.5$ and $50^{\circ} \mathrm{C}$.

(7) (Figure S5) The plot of $k_{\mathrm{o}}$ against $C_{\mathrm{o}}$ for the hydrolysis of human serum albumin catalyzed by $\mathrm{Cu}(\mathrm{II}) \mathrm{A}-\mathrm{PS}(\bullet)$ and $\mathrm{Cu}(\mathrm{II}) \mathrm{A}^{\text {cont }}-\mathrm{PS}(\circ)$ at $\mathrm{pH} 9.5$ and $50^{\circ} \mathrm{C}$.

(8) (Figure S6) The plot of $k_{\mathrm{o}}$ against $C_{\mathrm{o}}$ for the hydrolysis of human serum albumin catalyzed by $\mathrm{Cu}(\mathrm{II}) \mathrm{B}-\mathrm{PS}(\bullet)$ and $\mathrm{Cu}(\mathrm{II}) \mathrm{B}^{\text {cont }}$-PS (०) at $\mathrm{pH} 9.0$ and $50^{\circ} \mathrm{C}$. 
(9) (Figure S7) The plot of $k_{\mathrm{o}}$ against $C_{\mathrm{o}}$ for the hydrolysis of lysozyme catalyzed by $\mathrm{Cu}(\mathrm{II}) \mathrm{A}-\mathrm{PS}(\bullet)$ and $\mathrm{Cu}(\mathrm{II}) \mathrm{A}^{\text {cont }}$-PS (०) at $\mathrm{pH} 9.5$ and $50^{\circ} \mathrm{C}$.

(10) (Figure S8) The plot of $k_{\mathrm{o}}$ against $C_{\mathrm{o}}$ for the hydrolysis of lysozyme catalyzed by $\mathrm{Cu}(\mathrm{II}) \mathrm{B}-\mathrm{PS}(\bullet)$ and $\mathrm{Cu}(\mathrm{II}) \mathrm{B}^{\text {cont }}$-PS (०) at $\mathrm{pH} 9.5$ and $50^{\circ} \mathrm{C}$.

(11) (Figure S9) The plot of $k_{\mathrm{o}}$ against $C_{\mathrm{o}}$ for the hydrolysis of ovalbumin catalyzed by $\mathrm{Cu}(\mathrm{II}) \mathrm{A}-\mathrm{PS}(\bullet)$ and $\mathrm{Cu}(\mathrm{II}) \mathrm{A}^{\text {cont }}$-PS (०) at $\mathrm{pH} 9.5$ and $50^{\circ} \mathrm{C}$.

(12) (Figure S10) The plot of $k_{\mathrm{o}}$ against $C_{\mathrm{o}}$ for the hydrolysis of ovalbumin catalyzed by $\mathrm{Cu}(\mathrm{II}) \mathrm{B}-\mathrm{PS}(\bullet)$ and $\mathrm{Cu}(\mathrm{II}) \mathrm{B}^{\text {cont }}$-PS (०) at $\mathrm{pH} 9.5$ and $50^{\circ} \mathrm{C}$. 
(1) Experimental procedures for synthesis of A5 and A5 ${ }^{\text {cont }}$

Compounds A5 and A5 ${ }^{\text {cont }}$ were prepared according to the route of Scheme S1.

Scheme S1. Synthetic route to A5 and A5 $5^{\text {cont }}$
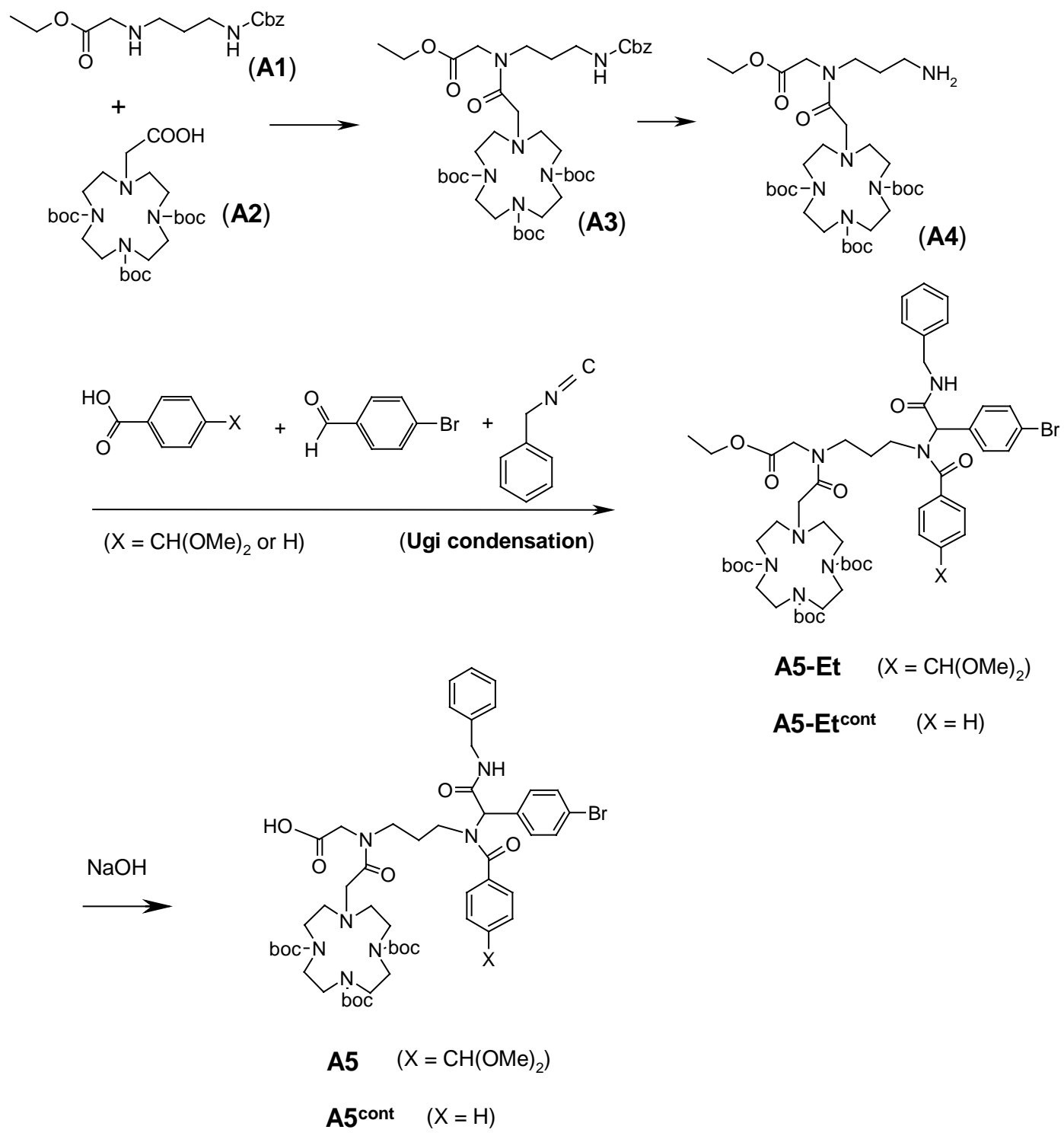

A5-Et $\quad\left(\mathrm{X}=\mathrm{CH}(\mathrm{OMe})_{2}\right)$

A5-Et ${ }^{\text {cont }} \quad(X=H)$

To the solution of propane-1,3-diamine $(8.4 \mathrm{~mL}, 100 \mathrm{mmol})$ in methylene chloride (MC) (200 mL) was added triethylamine (TEA) $(22 \mathrm{~mL}, 150 \mathrm{mmol})$. To the stirred solution, benzyl 
chloroformate $(14 \mathrm{~mL}, 100 \mathrm{mmol})$ was added dropwise. The reaction mixture was stirred for 3 hours, washed with $5 \%$ aq. citric acid $(50 \mathrm{~mL})$, and extracted with $\mathrm{MC}(3 \times 30 \mathrm{ml})$. The organic layer was washed with brine, dried over $\mathrm{Na}_{2} \mathrm{SO}_{4}$, and concentrated to obtain (3-aminopropyl)-carbamic acid benzyl ester as a colorless oil. $R_{f} 0.15$ (7:1 MC/MeOH-5 \% ammonium hydroxide).

To the solution of (3-amino-propyl)-carbamic acid benzyl ester (7.0 g, $34 \mathrm{mmol})$ in $\mathrm{MC}$ $(150 \mathrm{~mL})$ were added TEA $(14 \mathrm{~mL}, 100 \mathrm{mmol})$ and ethyl bromoacetate $(3.7 \mathrm{~mL}, 34 \mathrm{mmol})$. The reaction mixture was stirred for 12 hours at room temperature, washed with $5 \%$ aq. citric acid $(50 \mathrm{~mL} \times 3)$ and brine $(50 \mathrm{~mL})$, and dried over $\mathrm{Na}_{2} \mathrm{SO}_{4}$. The solvent was evaporated off, and column chromatography afforded (3-benzyloxycarbonylamino-propylamino)-acetic acid ethyl ester (A1) $(7.6 \mathrm{~g}, 72 \%)$ as a pale yellow oil. $R_{f} 0.3(20: 1 \mathrm{MC} / \mathrm{MeOH}) .{ }^{1} \mathrm{H}$ NMR (300 $\left.\mathrm{MHz}, \mathrm{CDCl}_{3}\right): \delta 7.32(\mathrm{~m}, 5 \mathrm{H}), 5.52(\mathrm{~m}, 1 \mathrm{H}), 5.11(\mathrm{~s}, 2 \mathrm{H}), 4.16(\mathrm{q}, 2 \mathrm{H}), 3.38(\mathrm{~m}, 2 \mathrm{H}), 3.28(\mathrm{~m}$, 2H), $2.66(\mathrm{~m}, 2 \mathrm{H}), 1.71(\mathrm{~m}, 1 \mathrm{H}), 1.64(\mathrm{~m}, 2 \mathrm{H}), 1.27(\mathrm{~m}, 3 \mathrm{H})$.

To a solution of [4,7,10-tris(t-butoxycarbonyl)-1,4,7,10-tetraazacyclododec-1-yl]-acetic acid (A2) (2.5 g, 4.8 mmol) (Jeon, J. W.; Son, S. J.; Yoo, C. E.; Hong, I. S.; Song, J. B.; Suh, J. Org. Lett. 2002, 4, 4155-4158) in $\mathrm{CH}_{3} \mathrm{CN}(80 \mathrm{~mL})$ cooled to $0 \square, O$-benzotriazol-1-yl$N, N, N^{\prime}, N$ '-tetramethyluroniumhexafluoro-phosphate (HBTU) (1.8 g, $\left.4.8 \mathrm{mmol}\right)$ was added. Thirty minutes later, A1 (1.4 g, $4.8 \mathrm{mmol})$ dissolved in dry $\mathrm{CH}_{3} \mathrm{CN}(10 \mathrm{~mL})$ was added followed by DIEA (2.1 mL $12 \mathrm{mmol})$. The reaction mixture was stirred for 1 hour at room temperature. The solvent was evaporated off and the residue was dissolved in EtOAc $(50 \mathrm{~mL})$. The solution was washed with $5 \%$ aq. citric acid $(50 \mathrm{~mL} \times 3)$ and brine $(50 \mathrm{~mL})$ and dried over $\mathrm{Na}_{2} \mathrm{SO}_{4}$. The solvent was evaporated off, and column chromatography on silica gel (1:1 EtOAc/hexane) afforded 10-\{[(3-benzyloxycarbonylamino-propyl)-ethoxycarbonylmethylcarbamoyl]-methyl\}-1,4,7,10-tetraaza-cyclododecane-1,4,7-tricarboxylic acid tri-t-butyl ester (A3) $(2.6 \mathrm{~g}, 69 \%)$ as a colorless oil. $R_{f} 0.35$ (2:1 EtOAc/hexane). ${ }^{1} \mathrm{H}$ NMR (300 MHz, $\left.\mathrm{CDCl}_{3}\right): \delta 7.33(\mathrm{~m}, 5 \mathrm{H}), 6.01(\mathrm{~m}, 1 \mathrm{H}), 5.08(\mathrm{~d}, 2 \mathrm{H}), 4.25-4.00(\mathrm{~m}, 4 \mathrm{H}), 3.58-3.26(\mathrm{br}, 18 \mathrm{H})$, 
3.00-2.79 (br, 4H), $1.75(\mathrm{~m}, 2 \mathrm{H}), 1.46-1.40(\mathrm{br}, 27 \mathrm{H}), 1.26(\mathrm{t}, 3 \mathrm{H})$. MS (MALDI-TOF) $\mathrm{m} / \mathrm{z}$ $807.93(\mathrm{M}+\mathrm{H})^{+}$, calcd for $\mathrm{C}_{40} \mathrm{H}_{67} \mathrm{~N}_{6} \mathrm{O}_{11} 807.99$.

A suspension of A3 (2.6 g, $3.3 \mathrm{mmol})$ and $2 \mathrm{~g}$ of $10 \% \mathrm{Pd} / \mathrm{C}$ in $30 \mathrm{~mL}$ of THF was stirred under $1 \mathrm{~atm}$ of $\mathrm{H}_{2}$ for 24 hours. When the catalyst was filtered off on Celite and the solvent was evaporated off, 10-\{[(3-amino-propyl)-ethoxycarbonylmethyl-carbamoyl]-methyl $\}$ 1,4,7,10-tetraaza-cyclododecane-1,4,7-tricarboxylic acid tri-t-butyl ester (A4) (2.1 g, $95 \%$ ) was obtained as a colorless oil. ${ }^{1} \mathrm{H}$ NMR $\left(300 \mathrm{MHz}, \mathrm{CDCl}_{3}\right): \delta 4.19-4.11(\mathrm{~m}, 4 \mathrm{H}), 3.76-3.37$ (br, 16H), 3.09-2.81 (br, 6H), $2.27(\mathrm{~m}, 2 \mathrm{H}), 1.86(\mathrm{~m}, 2 \mathrm{H}), 1.45(\mathrm{~m}, 27 \mathrm{H}), 1.26(\mathrm{t}, 3 \mathrm{H}) . \mathrm{MS}$ (MALDI-TOF) $m / z 673.82(\mathrm{M}+\mathrm{H})^{+}$, calcd for $\mathrm{C}_{32} \mathrm{H}_{61} \mathrm{~N}_{6} \mathrm{O}_{9} 673.85$.

Compound A4 (5.0 g, 7.4 mmol), 4-bromobenzaldehyde (1.4 g, 7.4 mmol), 4dimethoxymethylbenzoic acid (1.5 g, 7.4 mmol) (Keith, D. D.; Totora, J. A.; Ineichem, K.; Leimgruberk W. Tetrahedron 1975, 31, 2633-2636) were dissolved in MeOH (25 mL). Ten minutes later, the solution was added in one portion to a flask containing benzyl isocyanide $(0.87 \mathrm{~g}, 7.4 \mathrm{mmol})$. The solution was stirred at room temperature for 24 hours and evaporated. The residue was dissolved in MC (25 mL). The solution was washed with $5 \%$ aq. citric acid (25 mL), $5 \%$ aq. $\mathrm{Na}_{2} \mathrm{CO}_{3}(25 \mathrm{~mL})$, and brine $(25 \mathrm{~mL})$, and dried over $\mathrm{Na}_{2} \mathrm{SO}_{4}$. The solvent was evaporated off, and column chromatography afforded 10-[2-(\{4-[[benzylcarbamoyl-(4bromo-phenyl)-methyl]-(4-dimethoxymethyl-benzoyl)-amino]-butyl \}-ethoxycarbonyl-amino)2-oxo-ethyl]-1,4,7,10-tetraaza-cyclododecane-1,4,7-tricarboxylic acid tri-t-butyl ester (A5-Et) $(4.5 \mathrm{~g}, 53 \%)$ as a pale yellow solid. $R_{f} 0.3$ (1:1 EtOAc/hexane). ${ }^{1} \mathrm{H}$ NMR $\left(300 \mathrm{MHz}, \mathrm{CD}_{3} \mathrm{OD}\right)$ : $\delta 8.08(\mathrm{~d}, 1 \mathrm{H}), 7.61-7.58(\mathrm{~m}, 6 \mathrm{H}), 7.50-7.44(\mathrm{~m}, 4 \mathrm{H}), 7.34-7.28(\mathrm{~m}, 3 \mathrm{H}), 5.68(\mathrm{~s}, 1 \mathrm{H}), 5.41(\mathrm{~s}$, $1 \mathrm{H}), 4.50(\mathrm{~s}, 2 \mathrm{H}), 4.25-4.14(\mathrm{~m}, 4 \mathrm{H}), 3.51-3.26(\mathrm{br}, 24 \mathrm{H}), 3.00-2.90(\mathrm{br}, 4 \mathrm{H}), 1.82(\mathrm{~m}, 2 \mathrm{H})$, 1.47-1.42 (br, 27H), $1.27(\mathrm{t}, 3 \mathrm{H})$; MS (MALDI-TOF) $\mathrm{m} / \mathrm{z} 1154.27(\mathrm{M}+\mathrm{H})^{+}$, calcd for $\mathrm{C}_{57} \mathrm{H}_{83} \mathrm{BrN}_{7} \mathrm{O}_{13} 1154.20$.

The solution of A5-Et $(4.5 \mathrm{~g}, 3.9 \mathrm{mmol})$ in a mixture of aq. $2 \mathrm{M} \mathrm{NaOH}(30 \mathrm{~mL})$ and $\mathrm{MeOH}(30 \mathrm{~mL}$ ) was stirred for $30 \mathrm{~min}$. $\mathrm{MeOH}$ was evaporated under a reduced pressure and 
the aqueous layer acidified with citric acid to $\mathrm{pH} 4-5$ and extracted with $\mathrm{MC}(3 \times 30 \mathrm{ml})$. The organic layer was washed with brine, dried over $\mathrm{Na}_{2} \mathrm{SO}_{4}$, and concentrated in vacuo to obtain 10-[(\{3-[[benzylcarbamoyl-(4-bromo-phenyl)-methyl]-(4-dimethoxymethyl-benzoyl)-amino]propyl \}-carboxymethyl-carbamoyl)-methyl]-1,4,7,10-tetraaza-cyclododecane-1,4,7-tricarboxylic acid tri-t-butyl ester (A5) $(3.9 \mathrm{~g}, 87 \%)$ as a pale yellow solid. ${ }^{1} \mathrm{H}$ NMR $(300 \mathrm{MHz}$, $\left.\mathrm{CD}_{3} \mathrm{OD}\right): \delta 8.05(\mathrm{~d}, 1 \mathrm{H}), 7.52-7.49(\mathrm{~m}, 6 \mathrm{H}), 7.42-7.35(\mathrm{~m}, 4 \mathrm{H}), 7.30-7.26(\mathrm{~m}, 3 \mathrm{H}), 5.76(\mathrm{~s}$, 1H), 5.45 (s, 1H), 4.48 (s, 2H), 3.92-3.84 (br, 2H), 3.58-3.32 (br, 24H), 3.10-2.88 (br, 4H), $1.69(\mathrm{~m}, 2 \mathrm{H}), 1.46-1.41(\mathrm{br}, 27 \mathrm{H})$; MS (MALDI-TOF) $\mathrm{m} / \mathrm{z} 1126.20(\mathrm{M}+\mathrm{H})^{+}$, calcd for $\mathrm{C}_{55} \mathrm{H}_{79} \mathrm{BrN}_{7} \mathrm{O}_{13} 1126.15$.

10-\{2-[(4-\{Benzoyl-[benzylcarbamoyl-(4-bromo-phenyl)-methyl]-amino\}-butyl)-ethoxycarbonyl-amino]-2-oxo-ethyl \}-1,4,7,10-tetraaza-cyclododecane-1,4,7-tricarboxylic acid tri-tbutyl ester (A $5^{\text {cont }}$-Et) and 10-\{[(3-\{benzoyl-[benzylcarbamoyl-(4-bromo-phenyl)-methyl]amino \}-propyl)-carboxymethyl-carbamoyl]-methyl\}-1,4,7,10-tetraaza-cyclododecane-1,4,7tricarboxylic acid tri-t-butyl ester $\left(\mathrm{A} 5^{\mathrm{cont}}\right)$ were synthesized by the method described above for A5-Et and A5 by using benzoic acid instead of 4-dimethoxymethyl-bezoic acid. A5 ${ }^{\text {cont }}$-Et was obtained as a pale yellow solid. $R_{f} 0.25$ (1:1 EtOAc/hexane). ${ }^{1} \mathrm{H}$ NMR $\left(300 \mathrm{MHz}, \mathrm{CD}_{3} \mathrm{OD}\right): \delta$ 8.07 (d, 1H), 7.60-7.58 (complex, 7H), 7.47-7.41 (complex, 4H), 7.34-7.26 (complex, 3H), $5.45(\mathrm{~s}, 1 \mathrm{H}), 4.58(\mathrm{~s}, 2 \mathrm{H}), 4.15-4.11(\mathrm{~m}, 4 \mathrm{H}), 3.51-3.33(\mathrm{br}, 18 \mathrm{H}), 3.00-2.90(\mathrm{br}, 4 \mathrm{H}), 1.72(\mathrm{~m}$, 2H), 1.47-1.42 (br, 27H), $1.25(\mathrm{t}, 3 \mathrm{H}) . \mathrm{MS}$ (MALDI-TOF) $\mathrm{m} / z 1080.10(\mathrm{M}+\mathrm{H})^{+}$, calcd for $\mathrm{C}_{54} \mathrm{H}_{77} \mathrm{BrN}_{7} \mathrm{O}_{11}$ 1080.13. Compound $\mathrm{A} 5^{\text {cont }}$ was obtained as a pale yellow solid. ${ }^{1} \mathrm{H}$ NMR (300 $\left.\mathrm{MHz}, \mathrm{CD}_{3} \mathrm{OD}\right): \delta 8.05(\mathrm{~d}, 1 \mathrm{H}), 7.61-7.56(\mathrm{~m}, 7 \mathrm{H}), 7.48-7.42(\mathrm{~m}, 4 \mathrm{H}), 7.34-7.27(\mathrm{~m}, 3 \mathrm{H}), 5.45$ (s, 1H), 4.47 (s, 2H), 3.97-3.85 (br, 2H), 3.58-3.32 (br, 18H), 2.93-2.88 (br, 2H), 2.76-2.72 (br, 2H) $1.69(\mathrm{~m}, 2 \mathrm{H}), 1.45-1.41(\mathrm{br}, 27 \mathrm{H}) . \mathrm{MS}(\mathrm{MALDI}-\mathrm{TOF}) \mathrm{m} / z 1052.11(\mathrm{M}+\mathrm{H})^{+}$, calcd for $\mathrm{C}_{52} \mathrm{H}_{73} \mathrm{BrN}_{7} \mathrm{O}_{11} 1052.07$. 
(2) Experimental procedures for synthesis of $\mathrm{B} 1$ and $\mathrm{B} 1^{\text {cont }}$

Compounds B1 and B1 ${ }^{\text {cont }}$ were prepared according to the route of Scheme S2.

Scheme S2. Synthetic route to B1 and B1 $1^{\text {cont }}$

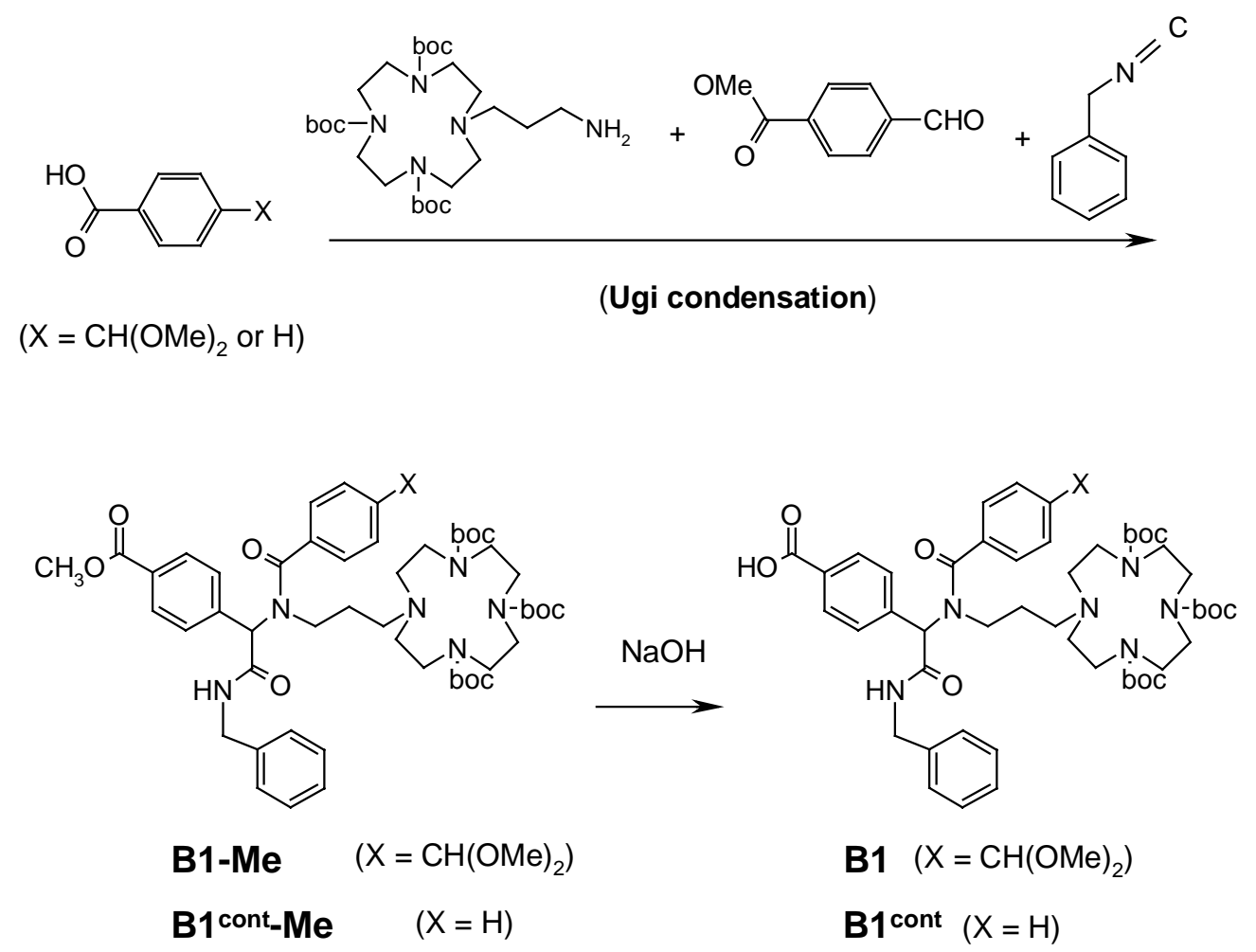

1-Aminopropyl-4,7,10-tri(t-butoxycarbonyl)-1,4,7,10-tetraaza-cyclodedecane (5.0 g, 9.4 mmol) (Roland, R.-K.; Kruppa, M.; König, B. J. Am. Chem. Soc. 2002, 124, 12999-13007), methyl 4-formylbenzoate (1.6 g, $9.4 \mathrm{mmol})$, and 4-dimethoxymethylbenzoic acid (1.9 g, 9.4 mmol) were dissolved in $\mathrm{MeOH}(25 \mathrm{~mL})$. Ten minutes later, the solution was added in one portion to a flask containing benzyl isocyanide $(1.1 \mathrm{~g}, 9.4 \mathrm{mmol})$. The solution was stirred at room temperature for 24 hours and evaporated. The residue was dissolved in MC $(25 \mathrm{~mL})$. The solution was washed with $5 \%$ aq. citric acid $(25 \mathrm{~mL}), 5 \%$ aq. $\mathrm{Na}_{2} \mathrm{CO}_{3}(25 \mathrm{~mL})$, and brine 
(25 mL), and dried over $\mathrm{Na}_{2} \mathrm{SO}_{4}$. The solvent was evaporated off, and column chromatography afforded 10-\{3-[[benzylcarbamoyl-(4-methoxycarbonyl-phenyl)-methyl]-(4dimethoxymethyl-benzoyl)-amino]-propyl $\}$-1,4,7,10-tetraaza-cyclododecane-1,4,7-tricarboxylic acid tri-t-butyl ester (B1-Me) as a pale yellow solid. $R_{f} 0.4$ (EtOAc/hexane 1:1). ${ }^{1} \mathrm{H}$ NMR (300 MHz, $\left.\mathrm{CD}_{3} \mathrm{OD}\right): \delta$ 8.10-8.04 (d, 2H), 7.60-7.38 (m, 5H), 7.33-7.25 (m, 6H), $5.82(\mathrm{~s}, 1 \mathrm{H})$, $5.40(\mathrm{~s}, 1 \mathrm{H}), 4.46(\mathrm{~s}, 2 \mathrm{H}), 3.92(\mathrm{~s}, 3 \mathrm{H}), 3.24-3.06(\mathrm{br}, 18 \mathrm{H}), 2.50-2.40(\mathrm{br}, 4 \mathrm{H}), 1.66(\mathrm{~m}, 2 \mathrm{H})$ 1.46-1.40 (br, 27H); MS (MALDI-TOF) $m / z 989.50(\mathrm{M}+\mathrm{H})^{+}$, calcd for $\mathrm{C}_{53} \mathrm{H}_{76} \mathrm{~N}_{6} \mathrm{O}_{12} 989.20$

The solution of B1-Me (1.5 g, $1.4 \mathrm{mmol})$ in a mixture of aq. $2 \mathrm{M} \mathrm{NaOH}(30 \mathrm{~mL})$ and $\mathrm{MeOH}(30 \mathrm{~mL})$ was stirred for 30 minutes. $\mathrm{MeOH}$ was evaporated under a reduced pressure and the aqueous layer was acidified with citric acid to $\mathrm{pH} 4-5$ and extracted with $\mathrm{MC}(3 \times 30$ $\mathrm{ml})$. The organic layer was washed with brine, dried over $\mathrm{Na}_{2} \mathrm{SO}_{4}$, filtered, and evaporated, to obtain 10-\{3-[[benzylcarbamoyl-(4-carboxy-phenyl)-methyl]-(4-dimethoxymethyl-benzoyl)amino]-propyl \}-1,4,7,10-tetraaza-cyclododecane-1,4,7-tricarboxylic acid tri-t-butyl ester (B1) $(1.6 \mathrm{~g}, 80 \%)$ as a pale yellow solid. $R_{f} 0.4$ (EtOAc/hexane $\left.1: 1\right) .{ }^{1} \mathrm{H}$ NMR $\left(300 \mathrm{MHz}, \mathrm{CD}_{3} \mathrm{OD}\right)$ : $\delta 8.10-8.04(\mathrm{~d}, 2 \mathrm{H}), 7.60-7.38(\mathrm{~m}, 5 \mathrm{H}), 7.33-7.25(\mathrm{~m}, 6 \mathrm{H}), 5.82(\mathrm{~s}, 1 \mathrm{H}), 5.40(\mathrm{~s}, 1 \mathrm{H}), 4.46(\mathrm{~s}$ 2H), 3.24-3.06 (br, 18H), 2.50-2.40 (br, 4H), 1.66 (m, 2H), 1.46-1.40 (br, 27H); MS (MALDITOF) $m / z$ 975.22 (M+H) ${ }^{+}$, calcd for $\mathrm{C}_{52} \mathrm{H}_{74} \mathrm{~N}_{6} \mathrm{O}_{12} 975.18$.

10-(3-\{Benzoyl-[benzylcarbamoyl-(4-methoxycarbonyl-phenyl)-methyl]-amino\}-propyl)1,4,7,10-tetraaza-cyclododecane-1,4,7-tricarboxylic acid tri-t-butyl ester (B1 ${ }^{\text {cont }}$-Me) and 10(3-(benzoyl-(benzylcarbamoly-(4-carboxyl-phenyl)-methyl)-amino)-propyl)-1,4,7,10-tetraazacyclododecane-1,4,7-tricarbozylic acid tri-t-butyl ester $\left(\mathrm{B} 1^{\text {cont }}\right)$ were synthesized by the method described above for B1-Me and B1 by using benzoic acid instead of 4dimethoxymethyl-bezoic acid. $\mathrm{B} 1^{\text {cont }}$-Me was obtained as a pale yellow solid. ${ }^{1} \mathrm{H}$ NMR (300 $\left.\mathrm{MHz}, \mathrm{CD}_{3} \mathrm{OD}\right): \delta 8.10-8.04(\mathrm{~d}, 2 \mathrm{H}), 7.60-7.38(\mathrm{~m}, 6 \mathrm{H}), 7.33-7.25(\mathrm{~m}, 6 \mathrm{H}), 5.40(\mathrm{~s}, 1 \mathrm{H}), 4.46$ (s, 2H), 3.92 (s, 3H), 3.24-3.06 (br, 12H), 2.50-2.40 (br, 4H), 1.66 (m, 2H), 1.46-1.40 (br, 27H); MS (MALDI-TOF) $m / z$ 915.70 (M+H) ${ }^{+}$, calcd for $\mathrm{C}_{50} \mathrm{H}_{70} \mathrm{~N}_{6} \mathrm{O}_{10}$ 915.13. Compound 
B1 ${ }^{\text {cont }}$ was obtained as a pale yellow solid. ${ }^{1} \mathrm{H}$ NMR $\left(300 \mathrm{MHz}, \mathrm{CD}_{3} \mathrm{OD}\right): \delta 8.10-8.04(\mathrm{~d}, 2 \mathrm{H})$, 7.60-7.38 (m, 6H), 7.33-7.25 (m, 6H), $5.40(\mathrm{~s}, 1 \mathrm{H}), 4.46(\mathrm{~s}, 2 \mathrm{H}), 3.24-3.06$ (br, 18H), 2.50$2.40(\mathrm{br}, 4 \mathrm{H}), 1.66(\mathrm{~m}, 2 \mathrm{H}), 1.46-1.40(\mathrm{br}, 27 \mathrm{H})$; MS (MALDI-TOF) $\mathrm{m} / \mathrm{z} 901.22(\mathrm{M}+\mathrm{H})^{+}$, calcd for $\mathrm{C}_{49} \mathrm{H}_{68} \mathrm{~N}_{6} \mathrm{O}_{10} 901.10$. 
(3) (Figure S1) The plot of $k_{\mathrm{o}}$ against $C_{\mathrm{o}}$ for the hydrolysis of $\gamma$-globulin catalyzed by Cu(II)A$\mathrm{PS}(\bullet)$ and $\mathrm{Cu}(\mathrm{II}) \mathrm{A}^{\text {cont }}$-PS (०) at $\mathrm{pH} 9.5$ and $50^{\circ} \mathrm{C}$.

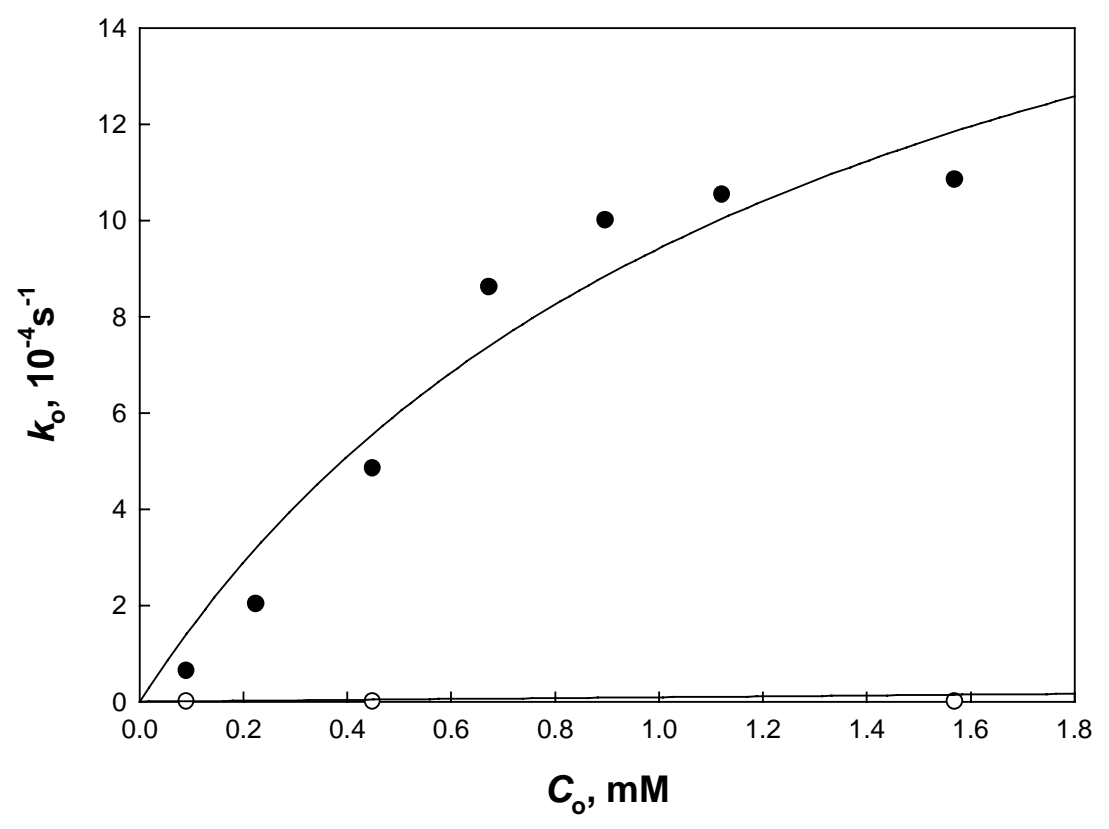

Figure S1 
(4) (Figure S2) The plot of $k_{\mathrm{o}}$ against $C_{\mathrm{o}}$ for the hydrolysis of $\gamma$-globulin catalyzed by $\mathrm{Cu}(\mathrm{II}) \mathrm{B}-\mathrm{PS}(\bullet)$ and $\mathrm{Cu}(\mathrm{II}) \mathrm{B}^{\text {cont }}$-PS (०) at $\mathrm{pH} 9.5$ and $50^{\circ} \mathrm{C}$.

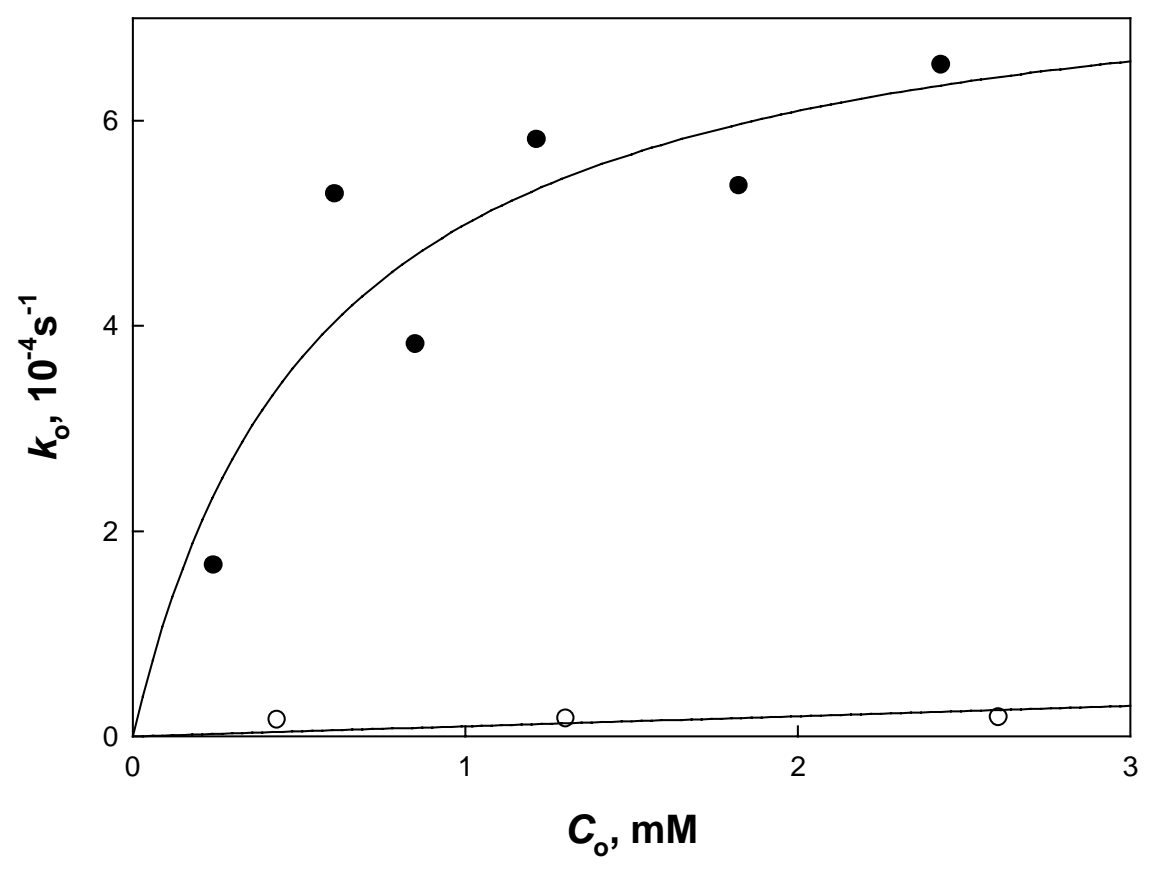

Figure S2 
(5) (Figure S3) The plot of $k_{\mathrm{o}}$ against $C_{\mathrm{o}}$ for the hydrolysis of bovine serum albumin catalyzed by $\mathrm{Cu}(\mathrm{II}) \mathrm{A}-\mathrm{PS}(\bullet)$ and $\mathrm{Cu}(\mathrm{II}) \mathrm{A}^{\text {cont }}$-PS (०) at $\mathrm{pH} 9.5$ and $50^{\circ} \mathrm{C}$.

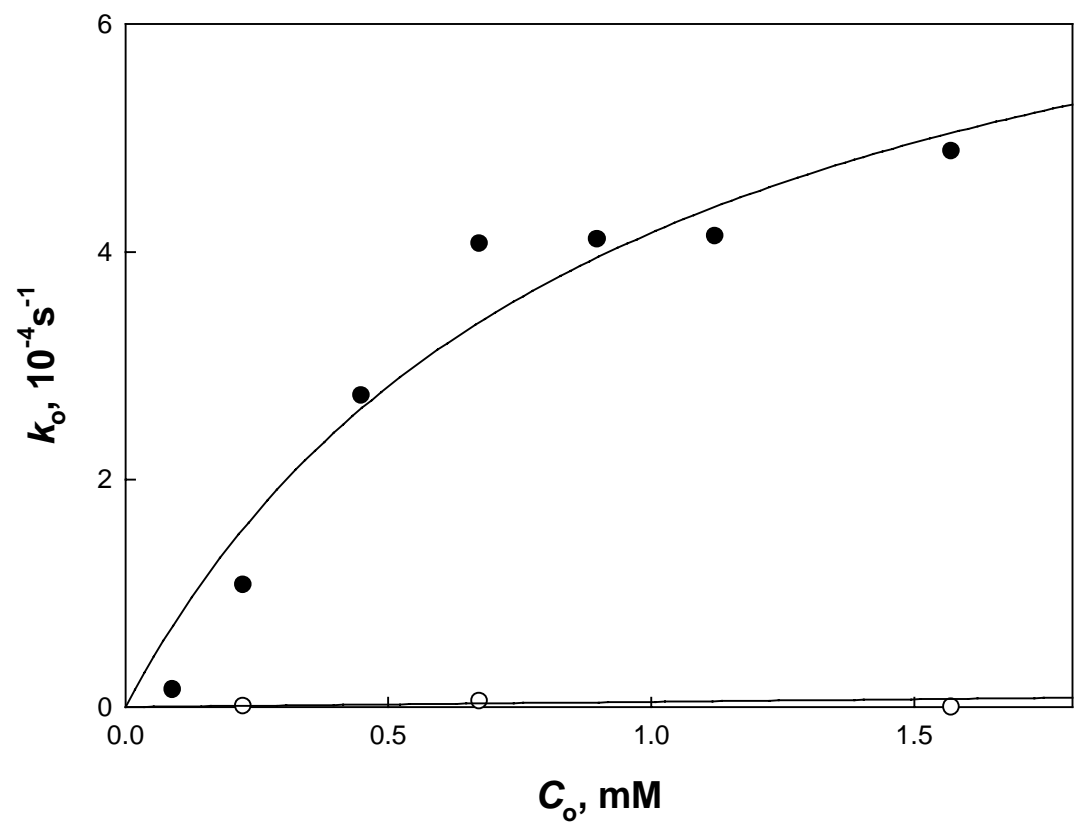

Figure S3 
(6) (Figure S4) The plot of $k_{\mathrm{o}}$ against $C_{\mathrm{o}}$ for the hydrolysis of bovine serum albumin catalyzed by $\mathrm{Cu}(\mathrm{II}) \mathrm{B}-\mathrm{PS}(\bullet)$ and $\mathrm{Cu}(\mathrm{II}) \mathrm{B}^{\text {cont }}$-PS (०) at $\mathrm{pH} 9.5$ and $50^{\circ} \mathrm{C}$.

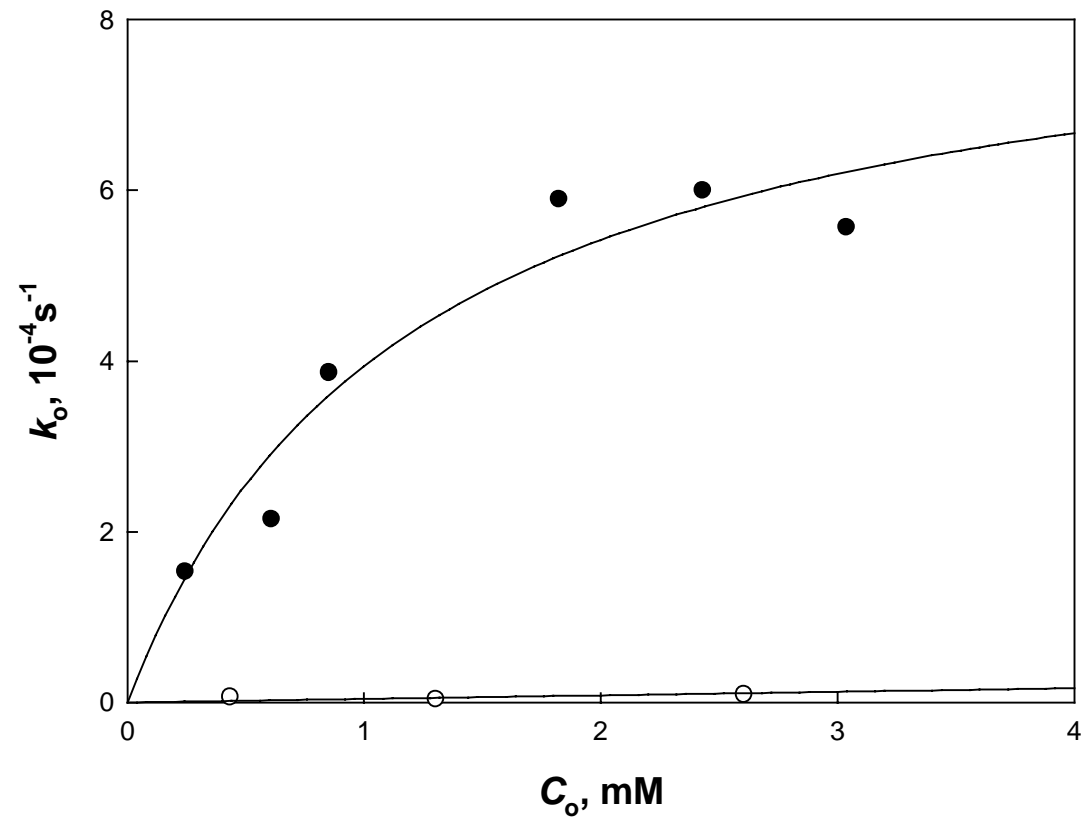

Figure S4 
(7) (Figure S5) The plot of $k_{\mathrm{o}}$ against $C_{\mathrm{o}}$ for the hydrolysis of human serum albumin catalyzed by $\mathrm{Cu}(\mathrm{II}) \mathrm{A}-\mathrm{PS}(\bullet)$ and $\mathrm{Cu}(\mathrm{II}) \mathrm{A}^{\text {cont }}$-PS (०) at $\mathrm{pH} 9.5$ and $50^{\circ} \mathrm{C}$.

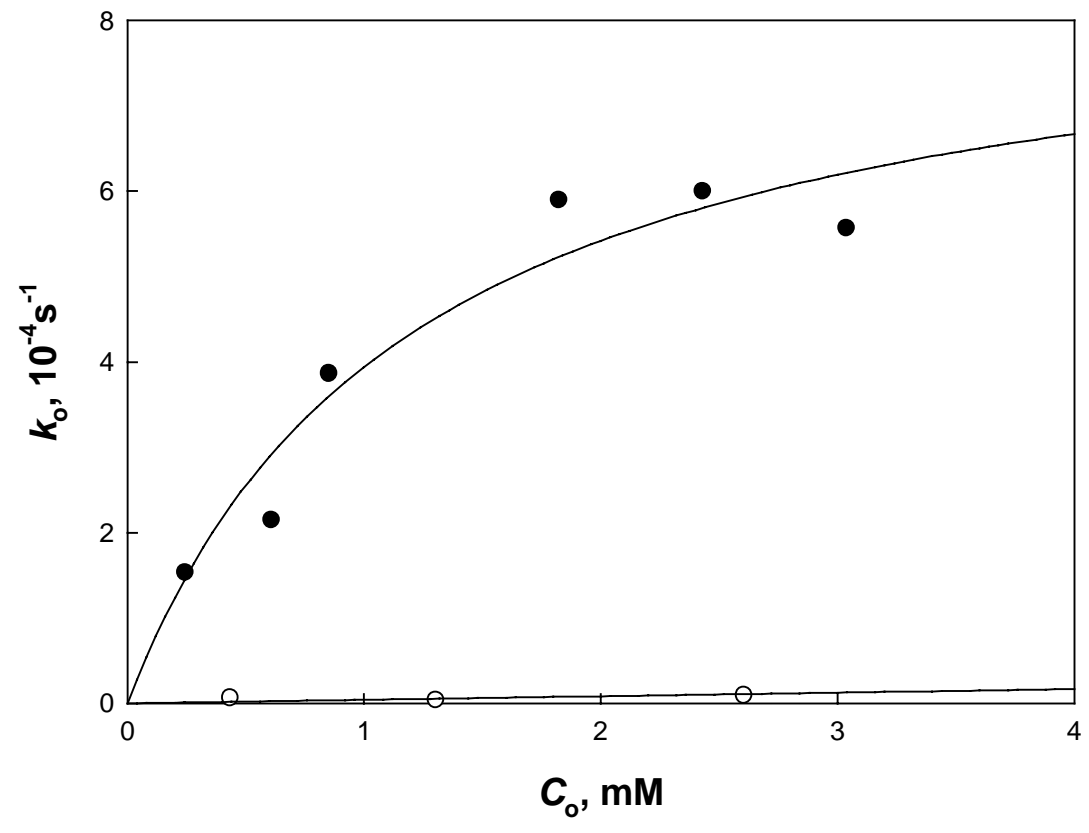

Figure S5 
(8) (Figure S6) The plot of $k_{\mathrm{o}}$ against $C_{\mathrm{o}}$ for the hydrolysis of human serum albumin catalyzed by $\mathrm{Cu}(\mathrm{II}) \mathrm{B}-\mathrm{PS}(\bullet)$ and $\mathrm{Cu}(\mathrm{II}) \mathrm{B}^{\text {cont }}-\mathrm{PS}(\circ)$ at $\mathrm{pH} 9.0$ and $50^{\circ} \mathrm{C}$.

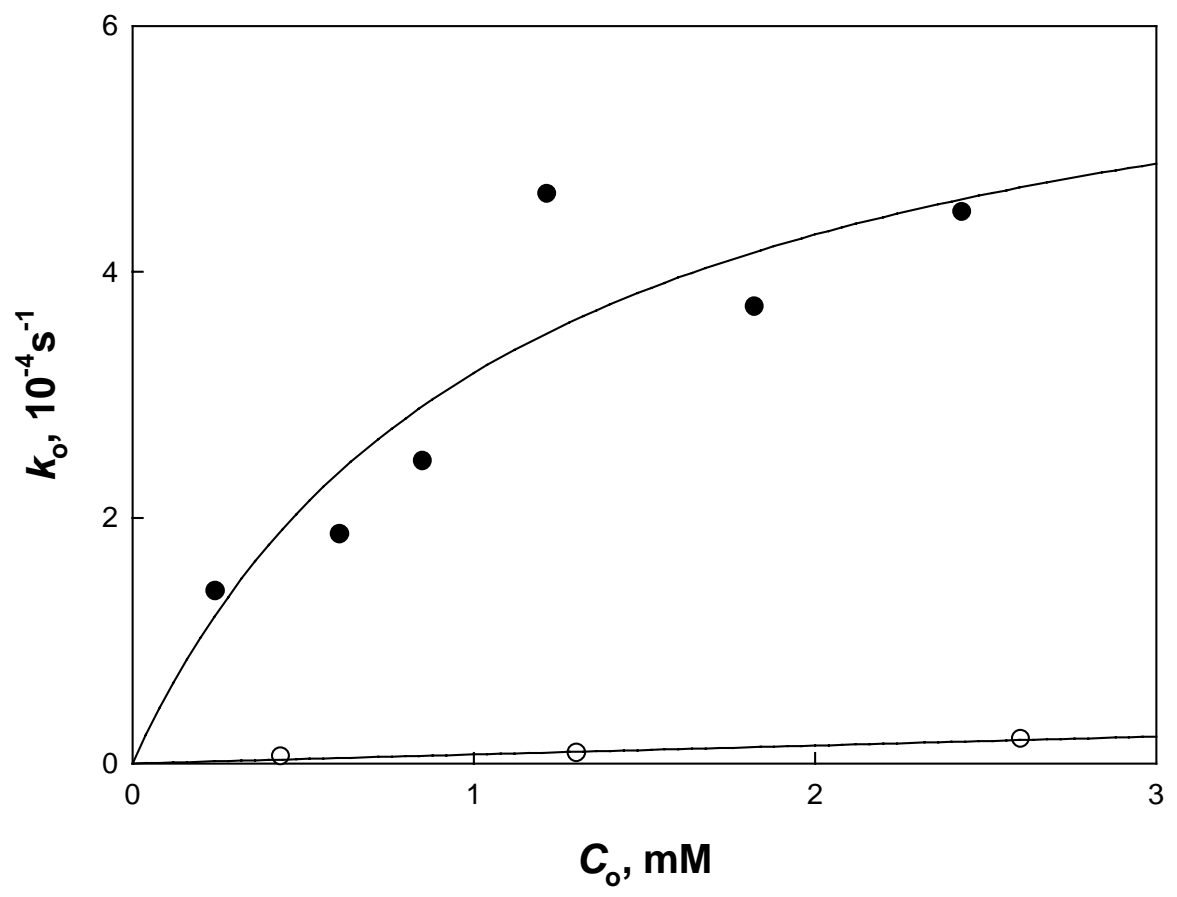

Figure S6 
(9) (Figure S7) The plot of $k_{\mathrm{o}}$ against $C_{\mathrm{o}}$ for the hydrolysis of lysozyme catalyzed by $\mathrm{Cu}(\mathrm{II}) \mathrm{A}$ $\mathrm{PS}(\bullet)$ and $\mathrm{Cu}(\mathrm{II}) \mathrm{A}^{\text {cont }}$-PS (०) at $\mathrm{pH} 9.5$ and $50^{\circ} \mathrm{C}$.

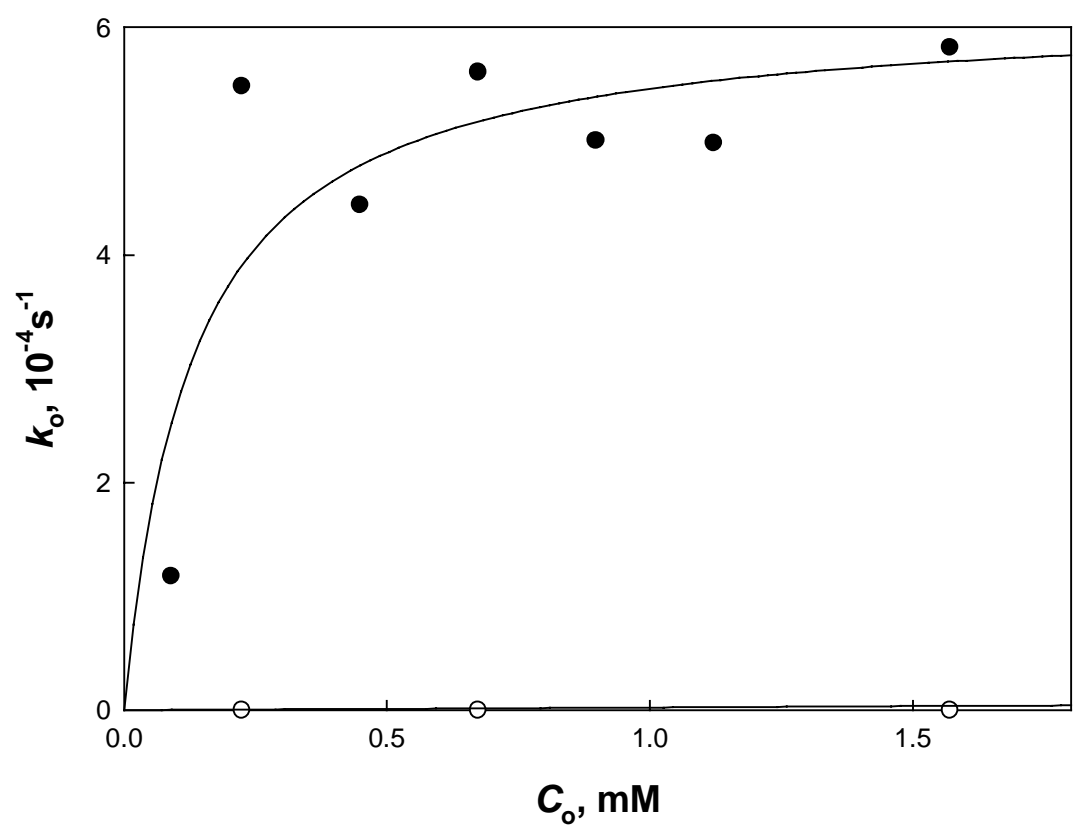

Figure S7 
(10) (Figure S8) The plot of $k_{\mathrm{o}}$ against $C_{\mathrm{o}}$ for the hydrolysis of lysozyme catalyzed by $\mathrm{Cu}(\mathrm{II}) \mathrm{B}-\mathrm{PS}(\bullet)$ and $\mathrm{Cu}(\mathrm{II}) \mathrm{B}^{\text {cont }}$-PS (०) at $\mathrm{pH} 9.5$ and $50^{\circ} \mathrm{C}$.

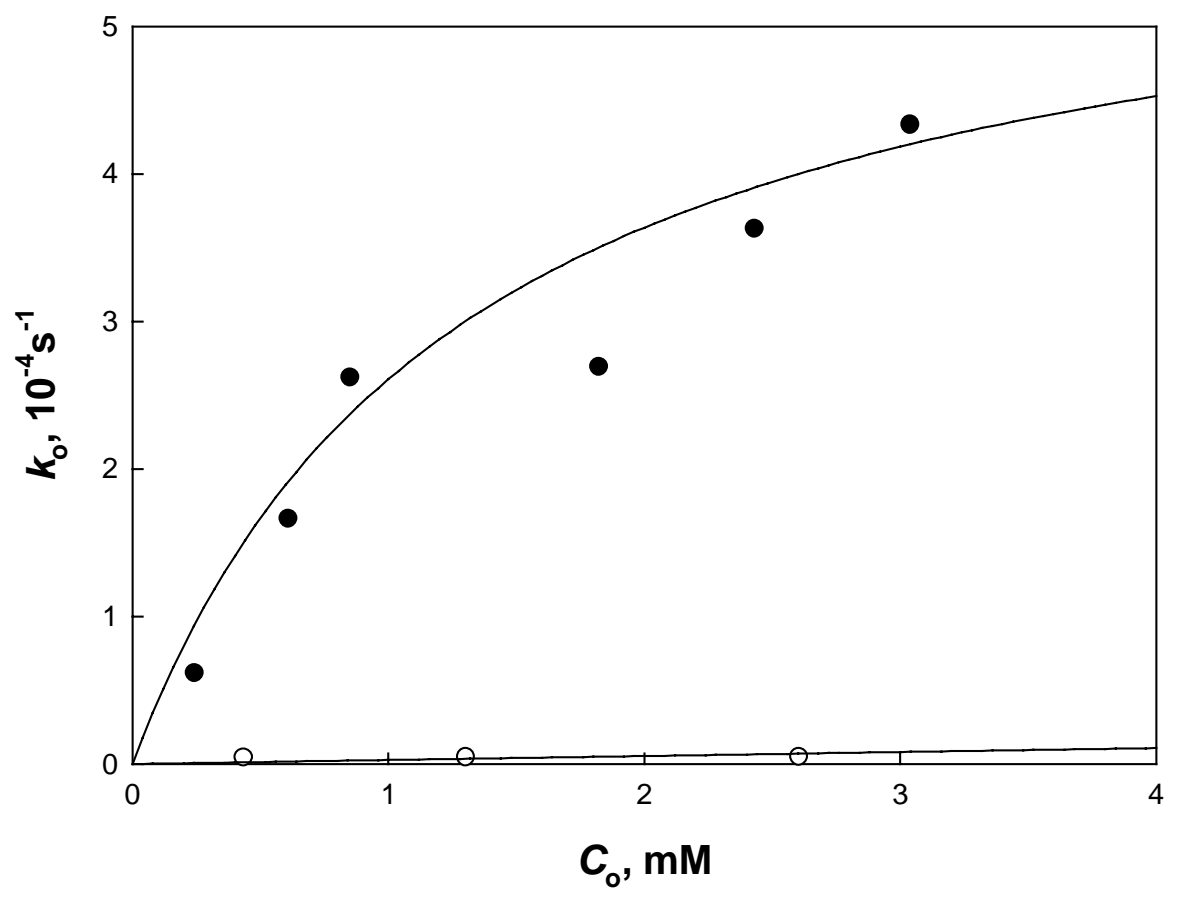

Figure S8 
(11) (Figure S9) The plot of $k_{\mathrm{o}}$ against $C_{\mathrm{o}}$ for the hydrolysis of ovalbumin catalyzed by $\mathrm{Cu}(\mathrm{II}) \mathrm{A}-\mathrm{PS}(\bullet)$ and $\mathrm{Cu}(\mathrm{II}) \mathrm{A}^{\text {cont }}$-PS (०) at $\mathrm{pH} 9.5$ and $50^{\circ} \mathrm{C}$.

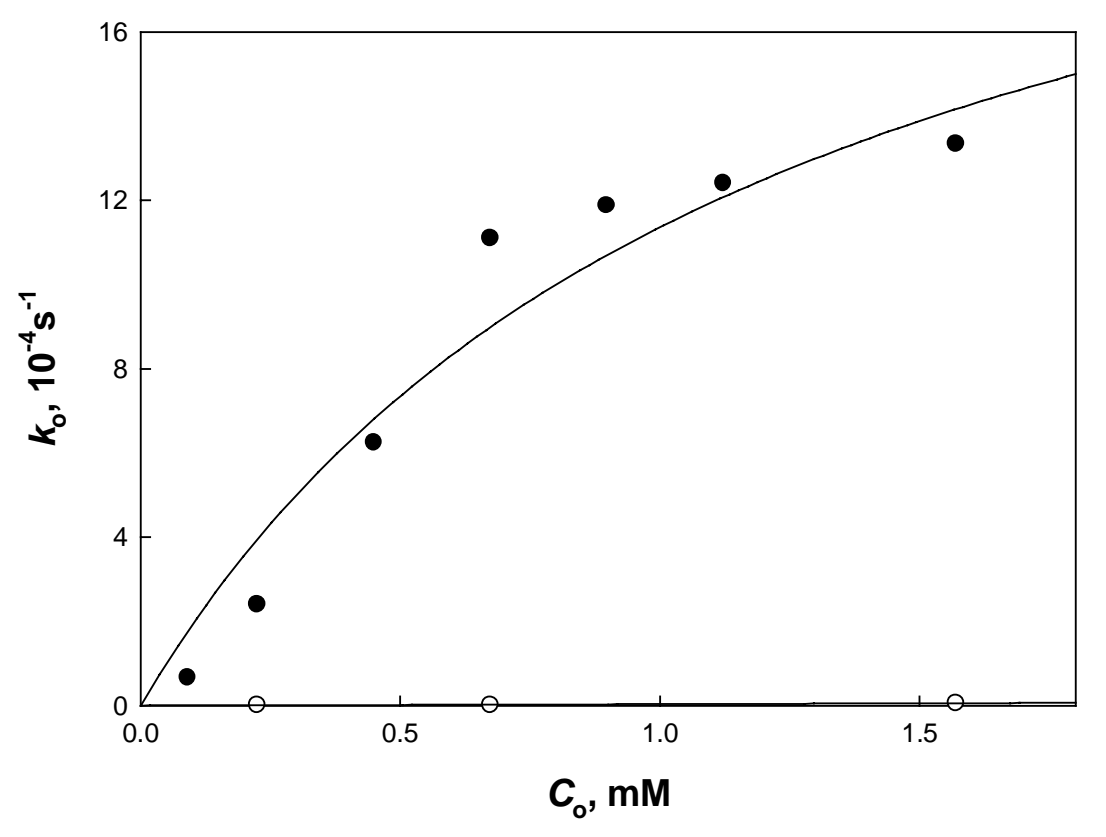

Figure S9 
(12) (Figure S10) The plot of $k_{\mathrm{o}}$ against $C_{\mathrm{o}}$ for the hydrolysis of ovalbumin catalyzed by $\mathrm{Cu}(\mathrm{II}) \mathrm{B}-\mathrm{PS}(\bullet)$ and $\mathrm{Cu}(\mathrm{II}) \mathrm{B}^{\text {cont }}$-PS (०) at $\mathrm{pH} 9.5$ and $50^{\circ} \mathrm{C}$.

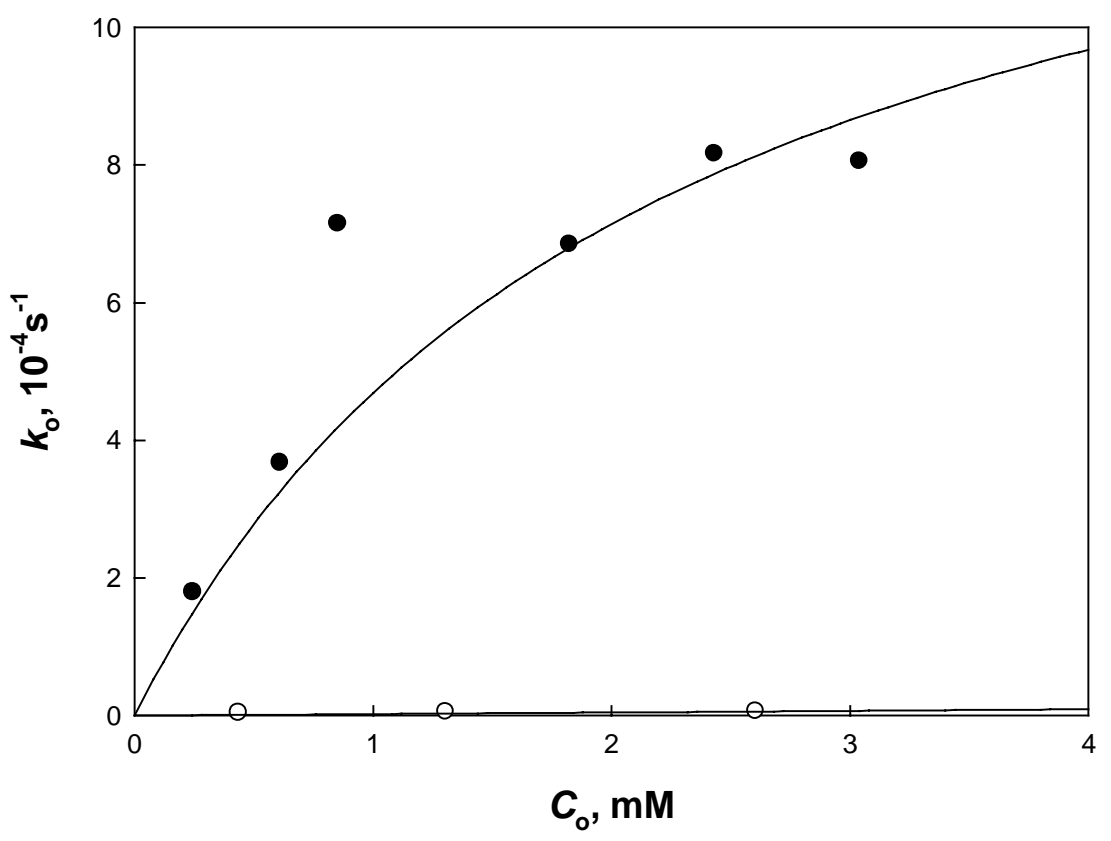

Figure S10 